\title{
Does the local coronary endothelial dys- function exist? Potential implications for cardiac cellular therapy
}

\author{
Alexander S. Nemkov, Zhang Yi \\ First St. Petersburg State I. Pavlov Medical University, St. Petersburg, Russia
}

Professor Dr. Alexander S. Nemkov. Department of Cardiac Surgery Bo. 2, The First St. Petersburg State I. Pavlov Medical University, L. Tolstoy St. 6-8, 197089, St. Petersburg, Russia

\section{Summary}

Endothelium is a cellular layer lining blood vessels in either a human organ or tissue. For decades, protective and barrier functions were considered to be the main property of vascular endothelium. Over last 20 years, however, endothelium is also considered an active endocrine organ which, due to secretion of multiple enzymes, metabolic and growth factors, may exert sufficient regulatory effects upon heart and blood vessels, thus playing an important role in pathogenesis of certain cardiovascular disorders. Accumulating data on changing interactions between heart vascular endothelium and myocardium allow us to suggest an additional local function for coronary endothelium, i.e., a proposed production
Phone: +7 (921) 7950047

E-mail: nemk_as@mail.ru

\section{Introduction}

According to a classical determination, vascular endothelium represents a monolayer of flat cells by mesenchymal origin that are lining the inner lumen of blood and lymph vessels, as well as heart chambers. For a long time, vascular endothelium was regarded only as a protective layer separating blood from inner vascular envelopes. By the end of XX century, after awarding a Nobel Prize (1998) in Physiology and Medicine to R. Furchgott, L.S. Ignorro, F. Murad "for their discoveries concerning nitric oxide as a signaling molecule in the cardiovascular system", a broader concept emerged which covers different humoral mechanisms of cardiovascular system regulation under normal and pathological conditions. This approach aimed to elucidate a role of endothelium in pathogenesis of arterial hypertension and other cardiovascular disorders. Hence, vascular endothelium could be viewed as an active secretory organ which is the of biologically active substances by endothelial cells, and their effects upon metabolism, functioning, survival and regeneration of cardiomyocytes. The discussion article presents analysis of distinct studies concerning cellular therapy in human heart diseases. These data are favoring a hypothesis about additional role of endothelium in cardiac function, and offer a potential ability to correct endothelial dysfunction by means of cellular therapy.

\section{Keywords}

Heart, coronary artery disease, endothelial dysfunction, cellular therapy, dilated cardiomyopathy. biggest structure in a human body. Large total vascular area and penetration to all organs provides extended influence of endothelium upon either tissue structure. Five specialized types of endotheliocytes could be discerned by morphofunctional criteria including fenestrated, sinusoid-like, ethmoid cells, and endothelium of high postcapillary venules [1-3]. Along with common gene activation mechanisms, a distinct endothelial phenotype is acquired due to local microenvironment and interactions with adjacent cells, also being influenced by intravascular hemodynamic factors.

\section{Endothelial functions and secretory factors}

The following functions of endothelial cells are widely known, i.e., vasomotor, hemostatic, adhesive, angiogenic effects. These actions are determined by levels of appropriate active 
protein factors produced by endothelium. Sometimes, these factors exert reciprocal effects upon the vascular wall [3].

E.g., vasomotor function of endothelium is determined by a vasoconstrictor complex, i.e., endothelin-1 (ET-1), thromboxane A2, 20-HETE (20-hydroxyeicosotetraenic acid), angiotensin II, being in balance with vasodilators (nitrogen monoxide, NO; prostacycline (PGI2); endothelial hyperpolarizing factor (EDHF), natriuretic peptides(BNP, C-type NP), adrenomedullin).

A set of compounds determines thromboresistance (NO, PGI2, PGE2, thrombomodulin (TM), tussue factor pathway inhibitor (TFPI), tissue plasminogen activator ( $t-P A)$, urokinase,plasminogen and urokinase inhibitors, antithrombin III, protein $C$ receptors, protein $S$, annexin $A 5$ ), thus counteracting some thrombogenicity factors of the vascular wall (von Willebrand factor (vWF), tissue factor (TF), plasminogen activator inhibitors (PAI-1 and PAI-2).

Adherence function of endothelium is controlled by adhesive molecules from the immunoglobulin superfamily (ICAM-1 (Intercellular adhesion molecule, CD54a), ICAM-2 (CD102), PECAM-1 (Platelet/endothelial cell adhesion molecule, CD31), VCAM-1 (Vascular cellular adhesion molecule, CD106)), like as selectins (E-selectin, P-selectin).

Angiogenic function of endothelium depends on production of vascular endothelial growth factor (VEGF), fibroblast growth factor (bFGF), platelet-derived growth factor (PDGF), insulin-like growth factor (IGF-1), transforming growth factor (TGF- $\beta$ ) [3].

Some common functions are inherent to endothelial cells of either location. Their activity and shifted balance are connected, e.g., with hemodynamic fluctuations, as well as with damaging effects of mechanical, ischemic, or toxic factors. Moreover, concentration of a biologically active substance may sufficiently modify biological effect. I.e., at lower synthesis rates $(<1 \mathrm{mcM})$, direct $\mathrm{NO}$ effects are generally observed, which support cardiovascular functioning. At higher concentrations $(>1 \mathrm{mcM})$, indirect effects predominate which are determined by free-radical properties of NO products, e.g., its ability to produce peroxynitrites [4]. At the present time, bidirectional effects of these substances are known, with regard of their mutually additive, synergistic or inhibitory effects [5].

Along with well-known substances like nitric oxide (NO), prostacyclin (PGI2), endothelin-1 (ET-1), neuregulin-1 (NRG-1), the endothelial cells lining blood capillaries secrete many factors in adaptable fashion. Some factors were discovered recently, e.g., Dickkopf-3 (DKK3), periostin, thrombospondin-1 (TSP-1), TSP-4, follistatin (FST) and follistatin-like factors (Fstl1, Fstl3), apelin, connective tissue growth factor (CTGF), MicroRNA-146a factor [2-4]. Further in-depth studies have revealed their multiple isoforms which exhibit different properties. Combined effects of the mentioned biologically active substances upon specialized cells of distinct organs will be different, depending on functional characteristics of the given tissue. Intercellular interactions between endothelium and specialized somatic cells show tissue specificity, e.g., endothelium-cardiomyocyte interactions in cardiac tissues.

With aging and signs of age-dependent coronary pathology, endothelium is more scarcely regenerated, and becomes dysfunctional [6]. As a result, its ability to release vasoactive molecules such as acetylcholine (ACh), prostacyclin (PGI2), endothelium-derived hyperpolarizing factor (EDHF), and nitric oxide (NO) is reduced and the cellular response to these molecules is also impaired, also due to age-related higher production of reactive oxygen and nitrogen species, endothelin and angiotensin.

\section{Systemic and local endothelial dysfunction}

Sax et al. (1987) have shown that altered endothelial functions of skin microvessels in patients with microvascular coronary arterial disease (CAD) correlate with appropriate changes in myocardium [7]. This finding has allowed a view on endothelial dysfunction (ED) as a systemic pathological process, and served as a basis for development of non-invasive techniques for the vascular ED evaluation in available peripheral vessels.

Heart as an active muscular organ which reacts quite rapidly to the changes of its local blood supply. Regulation of muscular contraction, neuromuscular conduction system, myocardial metabolism and regeneration sufficiently depend on both neuro-endocrine effects and interactions between local cell populations. E.g., specific interactions between endothelium and cardiomyocytes exist within heart. These effects are determined by the balance of endothelium-secreted cytokines which may be shifted due to alterations of endothelium and cardiomyocytes. This imbalance may manifest as disturbed myocardial contraction, dilatation of cardiac chambers, altered heart rate, clinically presenting as a heart failure.

Different production rates and lifetime are demonstrated for biologically active substances produced by endothelium. The lifetime for products synthesized by the coronary endothelium is very short $(<1 \mathrm{sec})$, thus being limited by neighbouring cells, e.g., cardiomyocytes, and does not extend to entire cardiovascular system. Therefore, it is reasonable to specify a local endothelial function connected with endothelial-cardiomyocyte interactions.

\section{Local attraction and recruitment of injected bone marrow cells: role of endothelium}

Several experimental studies concerned final residence of marrow mononuclears injected either systemically or locally (Table 1). Comparative studies have shown much higher MNC capture when injected intracoronarily than via peripheral veins $[8,9]$. Intramyocardial injections resulted in even higher cell capture in injured area [10]. Measurable rates of MNC homing in the heart were approximately $6-7 \%[9,11]$. 
Table 1. Local capture of bone marrow mononuclear cell (MNC) in experimental myocardial infarction in pigs

\begin{tabular}{|c|c|c|c|c|}
\hline Animal model & $\begin{array}{l}\text { Myocardial infarction } \\
\text { model }\end{array}$ & $\begin{array}{l}\text { MNC labeling and cell } \\
\text { fraction captured in } \\
\text { heart }\end{array}$ & $\begin{array}{l}\text { Characteristicsof local } \\
\text { capture }\end{array}$ & Reference \\
\hline Pigs & $\begin{array}{l}\text { Balloon occlusion model; } \\
\text { MNCs injected intracoro- } \\
\text { narly, or into peripheral } \\
\text { vein } 7 \text { days later }\end{array}$ & $\begin{array}{l}\text { Fluorescent marker and/ } \\
\text { or 99mTc, scintigraphy }\end{array}$ & $\begin{array}{l}6+1.7 \% \text { retained in the heart, } \\
\text { both in presence or absence } \\
\text { of } M I, \text { no local cell homing } \\
\text { after intravenous injections }\end{array}$ & Forest et al. (2010) [9] \\
\hline Pigs & $\begin{array}{l}\text { Coronary occlusion, } \\
\text { MNCs intracoronarly or } \\
\text { intramyocardially }\end{array}$ & $\begin{array}{l}\text { "'In-labeled MNCs, SPECT } \\
\text { detection }\end{array}$ & $\begin{array}{l}\text { Intramyocardial injection: } \\
\text { MNCs remained in the injured } \\
\text { area; intracoronary route: } \\
\text { a minor portion retained in } \\
\text { heart }\end{array}$ & $\begin{array}{l}\text { Mäkelä J et al. (2009) } \\
\text { [10] }\end{array}$ \\
\hline Pigs & $\begin{array}{l}\text { 0cclusion of left ante- } \\
\text { rior descending (LAD) } \\
\text { coronary artery for } 90 \\
\text { min., intracoronary MNC } \\
\text { injected } 7 \text { days later }\end{array}$ & $\begin{array}{l}\text { 18F-fluoro-deoxy-glucose } \\
\text { (18F-FDG), dual-nuclide } \\
\text { SPECT imaging }\end{array}$ & $\begin{array}{l}6.8+1.8 \% \text { retained in infarcted } \\
\text { area }\end{array}$ & Qian H et al. (2007) [11] \\
\hline Pigs & $\begin{array}{l}60 \text {-min balloon occlusion } \\
\text { in the mid LAD. bone } \\
\text { marrow MNCs injected } \\
\text { intracoronarily or intra- } \\
\text { venously }\end{array}$ & $\begin{array}{l}\text { PKH67 dye labeling } \\
\text { of MNCs, PKH(+) cells } \\
\text { detected by fluorescence } \\
\text { microscopy }\end{array}$ & $\begin{array}{l}\text { Labeled cells found in infarct- } \\
\text { ed myocardium, number of } \\
\text { PKH(+) cells was 10-fold high- } \\
\text { er after intracoronary than } \\
\text { after intravenous injection }\end{array}$ & $\begin{array}{l}\text { Grøgaard et al. (2007) } \\
\text { [8] }\end{array}$ \\
\hline
\end{tabular}

Potential mechanisms of leukocyte attraction from blood flow to the vascular endothelium are discussed by Rao et al. [12]. The authors regard local recruitment of some leukocyte subpopulations to the tissues through endothelial-dependent mechanisms. These complex events are associated with endothelial secretion of various prothrombotic molecules, i.e., platelet-derived growth factor, von Willebrand factor, prostacyclin, NO, endothelin-1, expression of adhesion molecules (selectins, ICAM etc.). Short-distance leukocyte attraction is promoted by chemokines (MCP-1, MIP, RANTES etc.). The recruited lymphocytes and monocytes in turn, are also induced for secretion of proinflammatory factors and emigrate via endothelial layer, thus promoting tissue remodeling and neovasculogenesis. Hence, "molecular conversations" of endothelium with recruited leukocytes may play a key role in triggering the inflammatory response including tissue pathology following myocardial infarction.

A number of differentiation options is presented for the bone marrow mononuclear cells. Cellular composition of such MNC preparations is quite heterogenous, including $\mathrm{T}$ and $\mathrm{B}$ cells, monocytes, a small fraction of blood precursors etc. There are few studies concerning their in vivo fate. E.g., Fatkhudinov et al. [13] have injected autologous labeled bone marrow MNCs into the right and left coronary arteries in rats at day 30 after infarction. The labelled cells were then detected only in the damaged zone of the myocardium. However, these cells were not found in vascular walls. Interestingly, the transplanted cells were surrounded by thick collagen fibers with time, thus presuming their fibroblastic differentiation. In their later study, this group has shown that the injected mononuclear cells migrated to the cicatrix zone where they differentiated into fibroblasts and myofibroblasts [14]. Meanwhile, there was no evidence of their in vivo dif- ferentiation to cardiomyocytes, endothelial cells, or smooth muscle cells of vascular media. However, stimulation of angiogenesis and reparation of the myocardium was observed after BM MNC treatment, thus suggesting a positive effect for repair of heart function.

\section{Clinical evidence}

Cellular therapy of heart by means of autologous bone marrow has been worldwide in frames of clinical trials since 2002. After 15 years of its usage, its safety and positive effect are shown by most workers worldwide.

Primary pre-clinical studies [15], and initial clinical experience in Düsseldorf (Germany) performed and summarized by Strauer et al.[16], and in Rostock by Stamm et al. [17] used autologous bone marrow cells (ABMC) for treatment of coronary artery disease (CAD). Trials with CAD patients have revealed a positive functional response to the cellular therapy. Over the last 15 years, since introduction of this treatment modality, some distinct positive results are shown in randomized clinical studies. This treatment still did not become a standard for CAD patients, despite several meta-analyses have shown some benefits of the cellular therapy [18-20]

Over 2003-2017, a research team at the First St. Petersburg I. Pavlov Medical University (FSPMU) performed several studies dedicated to usage of autologous bone marrow hematopoietic cells (ABMC) for treatment of CAD patients and dilated cardiomyopathy. A total of 250 patients have received ABMC by 2017. The results of our studies were presented in several publications $[21,22,23,25]$. 
At the present time, upon additional analysis and further controlled studies, we conclude that the most positive effects of the cellular therapy could be explained by neoangiogenesis which could be observed following an effective cellular therapy. Most workers agree that a paracrine mechanism for the cytokine action is predominant under these conditions [24]. However, intercellular relations are known to be mediated by the cytokine effects. Therefore, a term of paracrine mechanism needs to be specified.

We attempted to ascribe some effects of the cellular therapy not only to angiogenesis, but also to possible correction of coronary endothelium using our own experience, as well as some facts from present publications.

During two years (2003-2004), after preclinical studies, we performed a pilot study in 12 patients which confirmed safety and reproducibility of ABMC intramyocardial injections (during aorto-coronary bypass surgery), or intracoronary infusion (during coronarography) to patients within first hours after ex vivo bone marrow separation. We have noted a positive effect of additional AMBC usage in both groups. However, we were unable to discern a favorable action of cellular therapy from positive effects of revasculatization.

From 2005 to 2011, we performed a controlled study of hydroxyethyl starch (HES)-separated AMBC upon intracoronary injections applied in patients with marked coronary lesions who were not fit for coronary bypass surgery, or coronary angioplastics and stenting [21]. This study included 97 CAD patients. These persons received ABMC via coronary vessels, without any special revascularization procedures. Control group consisted of 37 patients who did not receive ABMC injections, being only subjected to adequate conventional medical therapy. The patients received intracoronary injections of ABMC obtained by multiple sternal and iliac punctures and enriched by gradient centrifugation (900 g for $15 \mathrm{~min}$ at $1^{\text {-st }}$ stage, and $700 \mathrm{~g}$ for $15 \mathrm{~min}$ at $2^{\text {-nd }}$ stage) by means of HES solution. Mean total number of isolated nucleated cells was $6.8 \pm 3.5 \times 10^{8}$; mononuclear cell yield was $9 \pm 7.85 \times 10^{8}$; average CD34-positive cell number was $1.6 \pm 0.85 \times 10^{6}$. Total cell viability was about $95-98 \%$.

Clinical effect of ABMC injections in the study group was expressed in terms of decreased CAD symptoms by 1 functional class ( $68 \%$ of total), by 2 functional classes (12\%); $20 \%$ patients did not feel any changes. Such effect was evident at 6 to 9 months after single AMBC injections. We have observed a distinct gradual improvement of myocardial perfusion within the first year, as shown by means of positron emission tomography (PET) with isotopic ammonium, and increased myocardial metabolism according to PET studies with fluorodeoxyglucose (FDG). E.g., improved perfusion and myocardial metabolism were revealed as soon as 3 months later, however, more expressed positive changes are detected 6 and 12 months after single ABMC injection (Fig. 1). It should be noted that the detected increase of myocardial perfusion and improved cardiac metabolism represent two parallel, and, probably, interacting processes in heart after cellular therapy by local infusions of non-modified ABMC. Of note, this improvement of myocardial perfusion and enhanced local metabolism are two parallel, and, probably, interconnected
Legends to the figures:

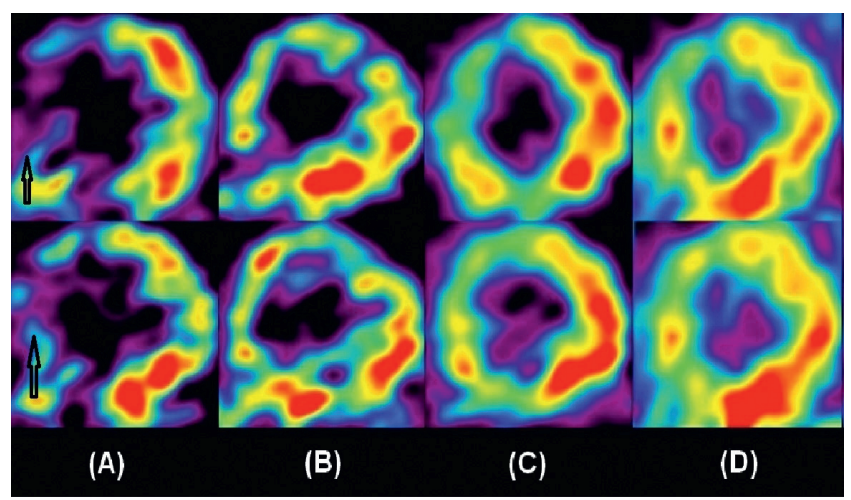

Figure 1. Metabolic pattern evaluated by positron emission tomography (PET) of myocardium: dynamics of fluordeoxyglucose (FDG) capture before and after intracoronary transplantation of bone marrow stem cells

At initial PET scans (A), a marked decrease in glucose metabolism is observed in the area of recent myocardial infarction (anteroseptal segment, arrow). After stem cell transplantation, a subsequent improvement is noted in the area of interest $(B$, 3 months); significant improvement ( $C, 6$ months), and normalization of ${ }^{18} \mathrm{~F}$-FDG capture (D, 12 months), thus being indicative for successive normalization of metabolic processes in the given area of left ventricle.

processes in heart after cellular therapy with intracoronary injection of non-modified ABMC to left ventricular myocardium.

These protective events were accompanied by increased myocardial contractibility, according to Echo-CG data, thus being ascribed to improved collateral blood flow. The revealed increase of collateral circulation could explain alleviation of coronary disorder and increased myocardial perfusion, as shown by SPECT and PET studies. Meanwhile, CAD functional class did not change in control group. This effect retained for ca. 3 years, followed by decreased antianginal effect at 4-5 years. Coronary angiography performed at these late terms showed stabililization of coronary arteries, without any significant progression of atherosclerotic lesions. It should be noted that impaired coronary circulation developed in presence of retained collateral blood flow.

Worth of note, we did not observe any cases of heart teratomas, pathological local ossifications, unfavorable immune reactions, or other adverse effects connected with ABMC injections over years of this study.

Consequent SPECT studies of myocardial perfusion in 19 patients have confirmed a decreased perfusion deficiency, as compared to initial levels, at the terms of up to 3 years after ABMC injections, thus being indicative for improvement of myocardial function. The decreased hypoperfusion area was patient-specific, and the year-by-year changes varied from $0.79 \pm 9.7 \%$ to $5.44 \pm 8.7 \%$ of hypoperfused area $(<60 \%$ of reference levels). 
Four years later, the average perfusion deficiency resumed to grow against initial level, i.e., myocardial blood supply changed to inferior values (Fig. 2). These findings prompted us to perform repeated ABMC injections four years later. Coronary angiography was performed before repeated $\mathrm{ABMC}$ injections. One should note that consecutive coronarography, as a rule, did not reveal any significant repair of initially affected coronaries. Meanwhile, the de novo developed collaterals continued their functioning after primary ABMC injection. Four patients were subjected to repeated intracoronary $\mathrm{ABMC}$ injection, without any other revascularization procedures. Distinct improvement of myocardial perfusion, according to SPECT data, and better clinical condition (decreased CAD functional class) were noted in all four patients, who underwent repeated intracoronary ABMC injections. 6 to 12 months later, a second wave of improved myocardial perfusion was observed, according to consequent SPECT examinations with technetryl labeling [25].

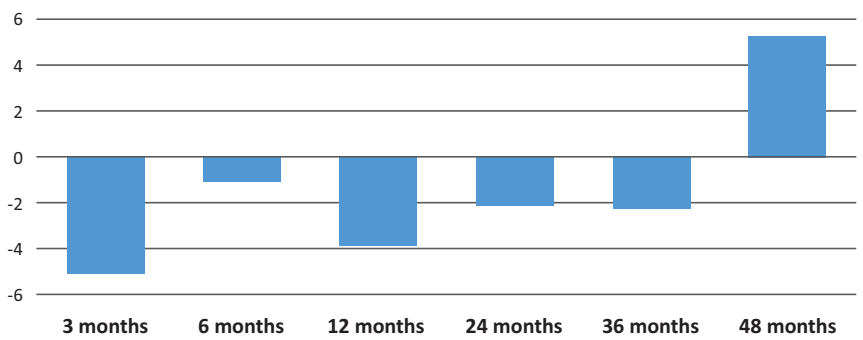

Figure 2. Time changes of median values of myocardial perfusion deficiency $(<60 \%)$ assessed by SPECT performed with Technetril in 19 patients. As compared to baseline levels, the perfusion deficiency proved to be decreased 1-2-3 years later, thus confirming improved blood supply (abscissa, 3-6-12-24-36-48 months). At $4^{\text {th }}$ year, the perfusion deficit was increased, thus presuming diminution of cardiac blood supply (Ordinate, $\Delta$ median of myocardial proportion with perfusion deficits (\%)

Such transient improvement of myocardial blood flow at 3-6-12 months after primary ABMC infusion followed by decreased heart blood supply at later terms (despite functioning collaterals), and repeated increase of blood supply at 3-6-12 months after repeated ABMC injections suggest some accessory bioactive factors responsible for the positive circulatory changes, probably, due to functional correction of coronary endothelial cells in severe CAD patients.

\section{Dilated cardiomyopathy}

Improvement of myocardial contractile ability was obtained also in a group of patients with dilated cardiomyopathy (DCMP), i.e., primary myocardial affection without coronary changes $[22,23]$. All these patients $(n=20)$ were devoid of coronary atherosclerotic lesions, thus confirming a DCMP diagnosis. The patients had cardiac insufficiency of NIHA functional class 3-4, with initial ejection fraction of 17 to $41 \%$. In all those cases, $A B M C$ were injected during coronary angiography, as intracoronary infusions of freshly isolated autologous marrow cells.
A positive clinical effect of this procedure was registered in 18 cases ( $90 \%$ of total), as reflected by decreased apnoe caused by physical loadings, decreased left ventricle end-systolic diameter, and increased left ventricle ejection fraction (LVEF). Notably, these positive effects allowed to decrease intensity of diuretic therapy (by tapering Furosemide dose, and switching to Torasemide). Assessment of metabolism by PET examination with fluorodeoxyglucose (FDG) has shown that the cellular therapy, lead to improved capture of the radiopharmaceutical in the segments with initially decreased metabolic level. Moderate increase of FDG capture was also noted in segments with virtually normal metabolism. One could suggest a direct effect of the cellular therapy upon cardiomyocytes. A distinct answer to this question is impossible, because myocardial microcirculation is affected in DCMP as well. Following cellular therapy, improved blood supply in DCMP was shown in the same segments as those with increased metabolism. The positive metabolic changes detected by PET were also found in DCMP patients within next 3-6 months after cellular therapy and were traceable over 2 years [23].

Altered myocardial blood supply in severe DCMP patients is associated with increased intramyocardial tension, and, accordingly, with disturbed blood supply at the microcirculatory level. One cannot exclude endothelial dysfunction of coronary microcirculation, and altered production of nitrogen monoxide and other substances negatively influencing myocardial contraction and coronary blood flow. Causal relations between the two processes (perfusion dynamics and intramyocardial tension) are hardly to discriminate at the present time.

Second ABMC injections in DCMP patients were performed in two cases 4-6 years after the first treatment, showing repeated improvement of clinical state (first of all, decreased apnoe) as reported by the both patients 6 to 9 months after cell therapy. Of note, repeated positive changes of left ventricle end-diastolic diameter, and accordingly, LVEF, are shown in these cases. These facts also suggest a functional mechanism of ABMC effects upon myocardium and endothelium. The issue of primary effect of ABMC injections upon coronary endothelium, with subsequent myocardial recovery, still remains open.

Thus, a repeated injection of ABMC 4-5 years later allows to achieve the second wave of clinical improvement. If such second injection is performed earlier, at 6-8 months after primary treatment (termed double infusion) the procedure may lead to sufficiently improved well-being, which is accompanied by marked positive changes of left ventricle end-systolic and -diastolic diameters, and more significant LVEF increase, than following a single injection. We have performed such double ABMC injection in only two patients. However, these cases are characterized by more sufficient cardiotropic effects than single ABMC infusions.

A successful experience with repeated injections of BM MNCs was also published by a group of workers from Frankfurt [24]. The authors used intracoronary injections of autologous bone marrow-derived mononuclear cells (BM-MNCs). The data from their local registry included 
297 post-infarction heart failure patients. The results of this study have shown that repeated intracoronary application of autologous bone marrow-derived cells is associated with a significant better 2-year survival compared with a single BM-MNC application (2-year survival 93.6 vs. $84.0 \%, \mathrm{P}=$ $0.03)$. Likewise, mortality is significantly lower at 2 -year follow-up compared with the mortality estimated by the use of the Seattle Heart Failure Model (SHFM) in patients receiving repeated BM-MNC application (observed mortality 6.4\%, predicted mortality $16.2 \%, \mathrm{P}=0.02)$. The repeated intracoronary administration of BM-MNC appears to be associated with improved clinical outcome compared with single treatment at 2 years. The authors propose a design of the multicentre randomized, controlled, open-label REPEAT trial in patients with chronic post-infarction heart failure.

\section{Discussion}

At the present time, exact mechanism of cellular therapy is not known. Some distinct positive clinical results are detected over 15 years of its implementation in cardiology. These successful data are presented in randomized clinical studies. Meta-analyses of 2012 and 2015 showed a distinct value when applying cellular therapy for CAD and DCMP treatment.

Development of collateral vascular network due to neoangiogenesis was demonstrated in majority of works concerning mechanism of stem cell action upon heart tissues in CAD. Some workers consider formation of new vascular collaterals to be the main effect of hematopoietic stem cell treatment.

A mechanism and consequences of bone marrow cell recruiting following a coronary arterial occlusion are suggested by Schaper [26]. In brief, the shear stressed endothelium leads, in particular, to high NO production and VEGF secretion by endothelial cells followed by MCP-1 release. These compounds cause attraction and homing of $\mathrm{T}$ cells and monocytes at the collateral vessels. The blood-derived mononuclear cells and degrade extracellular matrix (ECM) and produce vascular growth factors (VEGF), thus causing tissue remodeling and arteriogenesis mainly of the smooth muscle layer. Blood flow is partially restored which is indeed observed in clinical.

According to many authors, a cytokine or paracrine effect is understood to be an immediate mechanism of the cellular therapy, i.e., the transplanted cells are solely cytokine suppliers, including growth factors which provide augmented natural regeneration $[19,20]$. One may propose that the injected stem cells represent a kind of reservoirs containing growth factors that promote regeneration even when these cells are subsequently dying. This hypothesis is quite possible, especially if stem cell isolation was accompanied by their damage, growth factor leakage and subsequent death. In such cases, a real effect of the cellular therapy should not exceed 3-6 months, and we cannot consider a solely cytokine effect. However, a long-term duration of a positive effect from cellular therapy with autologous freshly isolated bone marrow cells is as long as 3-4 years in most cases, thus suggesting a stem cell-mediated regeneration of some heart cell populations [25].
Cardiomyocytogenesis as an important mechanism of heart regeneration, was shown by several works, and by present time, some data are accumulated in favor of cardiomyocyte regeneration [27]. The more sufficient arguments for cellular component of heart regeneration were reported by Anversa et al. [28], i.e., upon female-to-male heart transplantation, large numbers of male cells were revealed in female heart graft, thus suggesting a cellular regeneration mechanism in this setting. A mean number of male (Y chromosome-positive) cardiomyocytes was $18 \%$, compared to $20 \%$ among smooth muscle cells of arterioles, and 14\% of capillary endotheliocytes, as based on examination of eight female heart transplants in male recipients at different terms (4 to 552 days) posttransplant. This result suggests an intensive (probably via blood circulation) transfer of male cells (possibly, hematopoietic stem cells and endothelium precursors) to the female heart graft. Hence, one may note that a sufficient renewal occurs not only among cardiomyocytes, but also for smooth muscle cells of arterioles and heart capillary endothelium [28]. One may presume these cells to regenerate in native heart tissues in other diseases in absence of heart transplantation, thus supposing similar regeneration mechanisms.

Additional information on cellular but not only cytokine-mediated effects of injected stem cells was presented by a group of workers from Frankfurt [29] who performed experiments in mice containing a suicide gene introduced to their myocardial cells subjected to death, after their incorporation to myocardial syncytium, vascular endothelium and vascular wall. In this model of acute myocardial infarction, injection of bone marrow cells committed to endothelial differentiation lead to significant improvement of the myocardial contractibility. Provoked death of cells induced for endothelial differentiation lead to decreased cardiac output. Interestingly, provoked death of cells committed for myocardial differentiation did not exert such an effect. Moreover, elimination of endothelial cells with NO synthase expression caused a decreased density of capillaries and arteriolae [29]. These data point to a sufficient influence of endothelium upon functional ability of myocardium.

Endothelium layer regulates transendothelial transport, including stem cell transfer, due to increased production of adhesion molecules on the surface of endothelial cells. The cells of different phenotypes exhibited different ability for transendothelial migration in an in vitro model with bone marrow-derived endothelial cell line [30]. BMEC-1 cells support transmigration of hematopoietic progenitors and more mature hematopoietic cells, thus representing predominantly committed progenitor cells. One may suggest that recovery of endothelial function is accompanied by correction of transendothelial transport. The resulting interactions between endothelium and myocardium may play a sufficient role in heart tissue regeneration.

The first experimental study which demonstrated an effect of injected marrow precursors upon endothelial dysfunction was presented by the workers from Oklahoma University [31]. In murine experiment, they have shown that treatment with bone marrow endothelial precursors is followed by a decreased thickness of lipid plaque layers. This effect could 
be used in future for atherosclerosis therapy. In addition, the authors noted that the injected endothelial precursors promote NO production by endothelial cells of appropriate vessels, thus augmenting the endothelium-dependent vascular relaxation. The authors did not conclude on probable necessity of bone marrow cells for endothelial recovery, in order to correct altered endothelial function. However, the results of this study suggest such an option.

Interactions between endotheliocytes of coronary bed and cardiomyocytes are rather complex, multifaceted, and are mediated not only by nitrogen monoxide, but also by numerous substances produced by endothelial cells that, in turn, influence cardiomyocyte populations, for either increasing, or inhibiting their function [5]. Therefore, functional correction of coronary endothelium could be quite important for treatment of myocardial heart insufficiency.

By the present time, some new factors were studied, in order to treat chronic heart insufficiency, in particular, neuregulin. However, one should bear in mind that activation at certain regeneration stages may lead to evolvement of unfavorable consequences including neoplasia $[32,33]$.

Apparently, detailed studies of interactions between endotheliocytes and cardiomyocytes will take much time, like as search and clinical implementation of single synthesized biologically active substances. Today, however, basing on current results of cellular therapy performed in 250 patients over 15 years, one may presume that a local infusion of freshly isolated ABMC could exert favorable effects upon coronary blood flow and diminish clinical signs of heart insufficiency. Correction of endothelial dysfunction may be a sufficient component of this mechanism [25].

\section{Conclusion}

On the basis of current knowledge and data about endothelium and its effects upon functional state of myocardium and entire heart, one may conclude that endocardial and coronary bed endothelium cannot only be a protective barrier between blood flow and cardiomyocytes. Endothelium seems to be a complex and well-balanced secretory system which control functional cellular activity, metabolism, survival and regeneration of cardiomyocytes, due to interactions between different cell populations, by secreting short-range biological substances.

Local endothelial dysfunction plays a sufficient role in pathogenesis of such heart diseases as CAD and DCMP. Therefore, its correction, e.g., by intracoronary injection of freshly isolated ABMCs, may be an important therapeutic component for future treatment of these diseases. Our hypothesis on important role of endothelium in MNC recruitment to the damaged site seems to be supported by experimental and clinical evidence, but still needs additional studies to be confirmed.

\section{Acknowledgments}

The authors are much appreciated to Professor Boris V. Afanasyev, Director, R. Gorbacheva Memorial Research Insti- tute of Children Oncology, Hematology and Transplantation at the First St. Petersburg State I.Pavlov Medical University and to the Institute staff for a long-term cooperation when performing clinical studies.

\section{Conflict of interest}

No conflict of interest is reported.

\section{References}

1. Garlanda C., Dejana E. Heterogeneity of endothelial cells. Specific markers . Arterioscler. Thromb Vasc Biol 1997;17:1193-1202.

2. Michiels C. Endothelial cell functions. J Cell Physiol 2003 Sep;196(3):430-443.

3. Vasina LV, Petrishchev NN, Vlasov TD. Markers of endothelial dysfunction. Regional Haemodynamics and Microcirculation 2017; 16(61): 4-15 (In Russian).

4. Davis KL, Martin E, Turko IV, Murad F. Novel effects of nitric oxide. Annu Rev Pharmacol Toxicol 2001;41:203-236.

5. Lim SL, Lam CS, Segers VF, Brutsaert DL, De Keulenaer GW. Cardiac endothelium-myocyte interaction: clinical opportunities for new heart failure therapies regardless of ejection fraction. Eur.Heart Journal 2015; 36 (31): 2050-2060.

6. Ghebre YT, Yakubov E, Wong WT, Krishnamurthy P, Sayed N, Sikora AG, Bonnen MD. Vascular Aging: Implications for Cardiovascular Disease and Therapy. Transl Med (Sunnyvale) 2016; 6(4). pii: 183. doi: 10.4172/21611025.1000183.

7. Sax FL, Cannon RO 3rd, Hanson C, Epstein SE. Impaired forearm vasodilator reserve in patients with microvascular angina. Evidence of a generalized disorder of vascular function? N Engl J Med 1987;317:1366-1370.

8. Grøgaard HK, Sigurjonsson OE, Brekke M, Kløw NE, Landsverk KS, Lyberg T, Eriksen M, Egeland T, Ilebekk A. Cardiac accumulation of bone marrow mononuclear progenitor cells after intracoronary or intravenous injection in pigs subjected to acute myocardial infarction with subsequent reperfusion. Cardiovasc Revasc Med 2007;8(1):21-27.

9. Forest VF, Tirouvanziam AM, Perigaud C, Fernandes S, Fusellier MS, Desfontis JC, Toquet CS, Heymann MF, Crochet DP, Lemarchand PF. Cell distribution after intracoronary bone marrow stem cell delivery in damaged and undamaged myocardium: implications for clinical trials. Stem Cell Res Ther 2010;1(1):4. doi: 10.1186/scrt4.

10. Mäkelä J, Anttila V, Ylitalo K, Takalo R, Lehtonen S, Mäkikallio T, Niemelä E, Dahlbacka S, Tikkanen J, Kiviluoma K, Juvonen T, Lehenkari P. Acute homing of bone marrow-derived mononuclear cells in intramyocardial vs. intracoronary transplantation. Scand Cardiovasc J 2009;43(6):366-373.

11. Qian H, Yang Y, Huang J, Gao R, Dou K, Yang G, Li J, Shen R, He Z, Lu M, Zhao S. Intracoronary delivery of au- 
tologous bone marrow mononuclear cells radiolabeled by 18F-fluoro-deoxy-glucose: tissue distribution and impact on post-infarct swine hearts. J Cell Biochem 2007;102(1):64-74.

12. Rao RM, Yang L, Garcia-Cardena G, Luscinskas FW. Endothelial-dependent mechanisms of leukocyte recruitment to the vascular wall. Circ Res 2007; 101(3):234-247.

13. Fatkhudinov TKh, Slashcheva GA, Bol'shakova GB, Khokhlova ON, Arutyunyan IV, Bukharova TB, Murashev AN, Gol'dshtein DV. Directions of migration of bone marrow mononuclears after intracoronary transventricular injection. Bull Exp Biol Med 2009;148(4):713-718.

14. Baikova JP, Fatkhudinov TKh, Bolshakova GB, Buharova TB, Dubovaya TK, Kaktursky LV, Goldshtein DV. Pathways of bone marrow mononuclear cell differentiation after transplantation into postinfarction heart. Bull Exp Biol Med 2011;152(1):128-132.

15. Orlic D, Kajstura J, Chimenti S, Jakoniuk I, Anderson SM, Li B, Pickel J, McKay R, Nadal-Ginard B, Bodine DM, Leri A, Anversa P. Bone marrow cells regenerate infarcted myocardium. Nature 2001;410(6829):701-705.

16. Strauer BE, Brehm M, Zeus T, Köstering M, Hernandez A, Sorg RV, Kögler G, Wernet P. Repair of infarcted myocardium by autologous intracoronary mononuclear bone marrow cell transplantation in humans. Circulation 2002;106:1913-1918.

17. Stamm C, Westphal B, Kleine HD, Petzsch M, Kittner C, Klinge H, Schümichen C, Nienaber CA, Freund M, Steinhoff G. Autologous bone-marrow stem-cell transplantation for myocardial regeneration. Lancet 2003;361(9351):45-46.

18. Abdel-Latif A, Bolli R, Tleyjeh IM, Montori VM, Perin EC, Hornung CA, Zuba-Surma EK, Al-Mallah M, Dawn B. Adult bone marrow - derived cells for cardiac repair. A systematic review and meta-analysis. Arch Intern Med 2007;167: 989-997.

19. Jeevanantham V, Butler M, Saad A, Abdel-Latif A, Zuba-Surma EK, Dawn B. Adult bone marrow cell therapy improves survival and induces long-term improvement in cardiac parameters: A systematic review and meta-analysis. Circulation 2012;126:551-568.

20. Fisher SA, Doree C, Mathur A, Martin-Rendon E. Meta-Analysis of cell therapy trials for patients with heart failure. novelty and significance. Circ Res 2015;116:1361-1377.

21. Burnos SN, Nemkov AS, Belyı̆ SA, Lukashenko VI. Ejection fraction and sizes of the left ventricle of the heart after intracoronary administration of autologous mononuclear cells of the bone marrow in patients with coronary artery disease with low ejection fraction. Vestn Khir im Grekova 2011;170(4):16-19. [In Russian].

22. Sedov V, Nemkov A, Afanasiev B. Autologous intracoronary transplantation of mononuclear bone marrow cell in patients with dilated cardiomyopathy. Proc. Congr. Heart Failure, 2009; Nice, France, 30 May-2 June 2009. Abstract 1376.
23. Nemkov A, Sedov V, Beliy S, et al.. Changes of myocardial viability according to positron emission tomography after intracoronary application of stem bone marrow cells. Journal Cardiovasc Surg 2014; 55 (Suppl 2): 57-58.

24. Assmus B, Alakmeh S, De Rosa S, Bönig H, Hermann E, Levy WC, Dimmeler S, Zeiher AM. Improved outcome with repeated intracoronary injection of bone marrow-derived cells within a registry: rationale for the randomized outcome trial REPEAT. Eur Heart J 2016;37(21):1659-1666.

25. Nemkov A, Belyi S, Komok V et al. Correction of coronary endothelial dysfunction is a possible accessory mechanism for cellular therapy of the heart. Cell Ther Transplant 2016;5(2):33-39.

26. Schaper W. Collateral circulation: past and present. Basic Res Cardiol 2009;104(1):5-21.

27. Leri A, Kajstura J, Anversa P. Mechanisms of myocardial regeneration. Trends Cardiovasc Med 2011;21(2): 52-58.

28. Quaini F, Urbanek K, Beltrami AP, Finato N, Beltrami CA, Nadal-Ginard B, Kajstura J, Leri A, Anversa P. Chimerism of the transplanted heart. New Engl J Med 2002; 346:515.

29. Yoon CH, Koyanagi M, Iekushi K, Seeger F, Urbich C, Zeiher AM, Dimmeler S. Mechanism of improved cardiac function after bone marrow mononuclear cell therapy: role of cardiovascular lineage commitment. Circulation 2010;121:2001-2011.

30. Möhle R, Moore MA, Nachman RL, Rafii S. Transendothelial migration of CD34 " and mature hematopoietic cells: an in vitro study using a human bone marrow endothelial cell line. Blood 1997;89(1):72-80.

31. Yao L, Heuser-Baker J, Herlea-Pana O, Iida R, Wang Q, Zou MH, Barlic-Dicen J. Bone marrow endothelial progenitors augment atherosclerotic plaque regression in a mouse model of plasma lipid lowering. Stem Cells 2012;30: 27202731.

32. Gao R, Zhang J, Cheng L, Wu X, Dong W, Yang X, Li T, Liu X, Xu Y, Li X, Zhou M. Phase II, randomized, double-blind, multicenter, based on standard therapy, placebo-controlled study of the efficacy and safety of recombinant human neuregulin-1 in patients with chronic heart failure. J Am Coll Cardiol 2010;55(18):1907-1914.

33. Jay SM, Murthy AC, Hawkins JF, Wortzel JR, Steinhauser ML, Alvarez LM, Gannon J, Macrae CA, Griffith LG, Lee RT. An engineered bivalent neuregulin protects against doxorubicin-induced cardiotoxicity with reduced proneoplastic potential. Circulation 2013;128(2):152-161. 


\title{
Существует ли местная эндотелиальная дисфункция коронарных сосудов? Потенциальные приложения для клеточной терапии сердца
}

\author{
Александр С. Немков, Чжан И \\ Первый Санкт-Петербургский государственный медицинский университет им. И. П. Павлова, \\ Санкт-Петербург, Россия
}

\section{Резюме}

Эндотелий представляет собой клеточный слой, выстилающий кровеносные сосуды любого человеческого органа или ткани. В течение десятилетий, защитные и барьерные функции считались основными свойствами сосудистого эндотелия. На протяжении последних 20 лет, однако, эндотелий стал рассматриваться как активный эндокринный орган в связи с секрецией множества энзимов, метаболических и ростовых факторов, может оказывать существенные регуляторные воздействия на ткани сердца и кровеносных сосудов, тем самым играя важную роль в патогенезе определенных сердечно-сосудистых заболеваний. Накопление данных об изменении взаимодействий между эндотелием сосудов сердца и миокардом позволяет нам предположить дополнительную местную функцию коронарного эндотелия, т.е. предполагаемую продукцию биологически активных веществ клетками эндоте- лия и их эффекты на метаболизм, функционирование, выживание и регенерацию кардиомиоцитов. Данная статья предлагает обсуждение и анализ конкретных исследований, касающихся клеточной терапии при заболеваниях сердца у человека. Эти данные говорят в пользу гипотезы о дополнительной роли эндотелия в функционировании сердца и предлагают потенциальную возможность коррекции эндотелиальной дисфункции посредством клеточной терапии.

\section{Ключевые слова}

Сердце, заболевание коронарных артерий, эндотелиальная дисфункция, клеточная терапия, дилатационная кардиомиопатия. 